\title{
Orman yangınına hassas bölgelerde arazöz ile müdahale oranının belirlenmesi (Bartın Orman İşletmesi örneği)
}

\section{Determination of pumper truck intervention ratios in zones with forest fire potential: Case study for Bartın Regional Forest Directorate.}

\author{
Ayhan ATEŞOĞLU, Kenan MELEMEZ, Beyruni UĞUR
}

Bartın Üniversitesi Orman Fakültesi Orman Mühendisliği Bölümü

Özet

Küresel ısınma ve iklim değişikliği nedeniyle günden güne artmakta olan orman yangınlarının uzaktan algılama ve coğrafi bilgi sistemleri kullanılarak yapılan analizler yardımlarıla belirlenmesi ve haritalanması yapılacak müdahale ve planlamalar için önemlidir. Bu çalışmada gelecekte yangın planlamalarına altlık teşkil etmesi açısından örnek bir test alanı olarak Bartın Orman İşletme Müdürlüğü (OIM) seçilmiştir. Yöntem olarak, orman yangın tehlike haritalaması amaçlı bir model oluşturmak maksadıyla Analitik Hiyerarşi Süreci (AHP) matematik modeli seçilmiştir. Çalışmada arazi örtüsü tipi/vejetasyon durumu, eğim, bakı, yükseklik, ulaşım, yerleşim gibi yangını etkileyen faktörler araştırılmış, AHP kapsamında her bir faktöre ait gerekli istatistiki hesaplardan sonra etki değerleri hesaplanarak, modele yansıyacak ağırlık değerleri belirlenmiştir. Sonuç ürün çıktısı olarak, Bartın Orman İşletme Müdürlüğü kapsamında yangın tehlike haritası düşük, orta ve yüksek olmak üzere sınıflandırılmış haritası oluşturulmuştur. Çalışma alanının yangın riski açısından \%15’i yüksek, \%34'ü kısmı da orta derecede hassas alanlardan oluştuğu tespit edilmiştir. Çalışma alanı içerisindeki yangın emniyet yol ve şeritleri dahil tüm yol ağları ile bölgedeki yangınlara arazözlerin müdahale durumu araştırılmış ve arazözlerin yangına müdahale alanları tespit edilerek haritalanmıştır. Mevcut yol ağları ile yangın riski orta ve yüksek alanların \% 67.3’lük kısmına müdahale edilebildiği belirlenmiştir.

Anahtar kelimeler: Arazöz, CBS, Orman yangını, orman yol ağı, uzaktan algılama

\section{Abstract}

Forest fire hazard areas that increasing day by day due to climate change and global warming were identified and mapped by integrating GIS based and multi-criteria analysis to provide information about the area most likely to be affected by fire in the Bartın Forest Enterprise directorate, Turkey. The mathematics of Analytic Hierarchy Process (AHP) and the calculation techniques was implemented to develop the forest fire hazard assessment model used in this study. Fire-causing factors such as land cover type/vegetation condition, slope, aspect (insulation), altitude, road network and settlement data were used in this application. Forest fire hazard zones were delineated by assigning weights, obtained using AHP technique, to the classes of all the layers according to their sensitivity to fire or their fire-inducing capability. Forest fire hazard categories were classified in three groups as high, moderate and low. Almost $15 \%$ and $34 \%$ of the study area was identified to be under high-risk and moderate-risk zones. The status of pumper track intervention in zones with fire risk area and the sufficiency of existing forest roads within an existing forest network were investigated and a pumper truck intervention area map along existing roads was also mapped. It was found that the intervention area is $67.3 \%$ of the high-risk and moderate-risk zones with current road network.

Keywords: Forest fire, forest road network, GIS, pumper truck, remote sensing 


\section{GiRiş}

Modern ormancılığın amacı, ormanların devamlılığını sağlayacak optimal yararlanmayı elde etmektir. Bu amaca ulaşabilmek için ormanları çeşitli tehlikelere karşı korumak, gerekli önlemleri zamanında almak ve bu önlemlere karşın meydana gelecek tehlikelerle savaşa hazır bulunmak gerekir (Çanakçığlu 1993). Ormana zarar veren en önemli nedenler arasında bulunan orman yangınları, dünyada ormanların devamlılığını tehlikeye sokan etkenlerin başında gelmektedir. Her ne kadar yangın, doğal bir etmen olarak ekosistemde var olsa da, insanın ateşi kullanmayı öğrenmesi ile birlikte insan kaynaklı yangınlar ortaya çıkmaya başlamıştır (Kılıç, 2012). Yangınlar, dünya genelinde her yıl milyonlarca hektar orman alanının kaybolmasına, büyük oranda yangınla mücadele masraflarına, ormanların birçok işlevinin yok olmasına ve aynı zamanda can ve mal kayıplarına neden olabilen en önemli tehdittir. Her yıl dünyada ortalama 4 milyon hektar, Akdeniz kuşağında ise ortalama 550 bin hektar orman yanmaktadır (OGM, 2013).

Ülkemizin de içinde bulunduğu Akdeniz havzasındaki bazı ülkeleri incelediğimizde, birçok Avrupa ülkesinde orman yangınları en önemli tehdit olarak varlılarını devam ettirmektedir (JRC 2011). Ülkemizde ise 2000-2010 yıllarında ortalama 2070 adet orman yangını çıkmış ve 10343 ha alan yanmıştır (OGM, 2010). Türkiye'de orman yangınları ile ilgili istatistik bilgilerin tutulmaya başlandığı 1937 yılından 2009 yılına kadar geçen 73 yıla bakıldığında; toplam yangın adedinin 86769 , toplam yanan alanın ise 1617701 hektar olduğu görülmektedir. Buna göre yıllık ortalama yangın adedinin 1188.6; son yıllarda Akdeniz Havzasında sıcaklıkların artması ve yağış miktarındaki azalma şeklinde kendini hissettirmeye başlayan iklimsel değişikliklerin gelecekteki olası etkileri arasında yangın sıklığının artması da bulunmaktadır. Bu öğelerin dikkate alınması durumunda gelecekte yangın çıkma sayısında artış olabileceği tahmin edilmektedir. Dolayısıyla bu tür olasılıklar da dikkate alınarak her türlü önlemlerin alınması gerekmektedir (Bilgili ve ark. 2008). Gerek küresel ısınma gerekse iklimsel değişkenlikler ve ısınma eğilimi, orman yangınına hassas alanlarının son şeklini sürekli değiştiren en önemli faktör olmaktadır (Pinol ve ark.1998, Gillett ve ark. 2004, Goldammer ve ark. 2009, Öztürk ve ark 2010, Zhihua ve ark. 2012). Orman yangınlarını oluşturan ana faktörler topografya, arazi kullanımı ve vejetasyon örtüsüdür (Çepel, 1983; Ateşoğlu, 2014). Bu bağlamda öne çıkan etmenler yangın hassasiyetinde belirleyici olmaktadırlar (Brown ve ark. 1973). Özellikle arazi kullanımındaki insan faktörleri yangın çıkış nedenlerinin başında gelmektedir (Burke 1980, Caldararo 2002, Jian ve ark. 2007).

Orman yolları, ormanların işletilmesinde ağaçlandırma ve üretim olduğu kadar koruma, rekreasyon vb. sosyal aktiviteler için önemlidir (Melemez, 2013). Orman yangınlarına müdahalede mevcut yollardan yararlanma en temel koruma hizmeti olarak karşımıza çıkmaktadır. Yangının kısa sürede söndürülebilmesi için ulaşım büyük önem taşımaktadır. Yangın noktasına karasal ulaşım amacıyla orman yol şebekesi; orman yolları, yangın emniyet yol ve şeritleri kullanılmaktadır (Bilici, 2009). Özellikle düşük 
ve orta derece yangına hassas bölgelerde konuşlandırılmış helikopter ve uçak gibi havadan yangına müdahale araçları bulunmaması, mevcut yol ağı planının önemini daha da artırmaktadır. Orman yolları ormanın herhangi bir yerinde çıkan yangına ulaşmada ekiplerin yararlanabileceği en önemli karayolu ulaşım birimini oluşturur. Ormanın tüm noktalarına en kısa sürede ulaşmayı sağlayacak orman yolları ile yangın emniyet yol ve şeritleri ağı, yangına ulaşma suresini kısaltarak yangınla savaşın başarısında önemli bir etken olmaktadır (Mol ve Öymen, 1988). Yangın emniyet yolları ve yangın emniyet şeritleri, yangın çıkmadan önce doğal ve yapay engellerden yararlanılarak yapılan, çıplak veya örtülü olan ve yangının yayılmasını engelleyen tesislerdir. Yangına hassas bölgelerde kullanılan bu yolların orman yangınları gibi acil müdahale gerektiren durumlarda en kısa yoldan yangın noktasına ulaşılarak; söndürme organizasyonuna erken başlamayı, yanan alanı azaltarak yangının etkisini düşürmeyi sağlar (Bilici, 2009). Coğrafi Bilgi Sistemi yapısında geliştirilen doğal kaynakların değerlendirilmesine yönelik çok sayıda farklı modül bulunmaktadır (İnan, 2004; Bilici, 2009). Özellikle orman yangını haritalama işlemlerinde uzaktan algılama, coğrafi bilgi sistemleri ve farklı modellemeler yaygın olarak kullanılmakta, planlamalara altlık olmaktadır. (Castro ve ark. 1998, Jo ve ark. 2013, Setiawan ve ark. 2004, Dong ve ark 2006, Sağlam, 2008, Razali, 2010).
Bu çalışmada, Bartın Orman İşletme Müdürlüğü için yangın tehlike haritalaması yapılarak, çalışma alanı içerisinde, yangın emniyet yol ve şeritleri dahil tüm yollar ile bölgedeki yangınlara arazözlerin müdahale durumu araştırılmış ve yangına hassas olan alanlarda arazözlerin yangına müdahale alanları tespit edilerek haritalanmıştır.

\section{MATERYAL VE YÖNTEM}

\section{Materyal}

Araştırma alanı Zonguldak Orman Bölge Müdürlüğü, Bartın Orman İşletme Müdürlüğü sınırlarını kaplayan 3206' 43" ve 32 45' 39" doğu boylamı, 41ㅇ 34'33" ve 41은 31" kuzey paralelleri arasında bulunan yaklaşık 175000 ha alandır (Şekil 1). Batı Karadeniz Bölgesi bitki coğrafyası bakımından EuroSiberian (Avrupa-Sibirya) flora alanının Öksin alt flora alanında bulunmaktadır. Bartın ilinde doğal bitki örtüsü içinde; yüksek oranda orman vejetasyonu ile kıyı şeridinde bulunan yalancı maki vejetasyonu bulunmaktadır. Bölgedeki orman vejetasyonunda Meşe (Quercus sp.), Gürgen (Carpinus betulus), Kestane (Castenae sativa), Kayın (Fagus orientalis)'ın hakim olduğu yazın yeşil yapraklı orman ile Sarıçam (Pinus sylvestris), Karaçam (Pinus nigra), Göknar (Abies bornmülleriana)'dan oluşan iğne yapraklı orman ve bu türlerin bir araya gelerek oluşturduğu (karışık) ormanlar bulunmaktadır. (Ateşoğlu and Tunay 2010). 


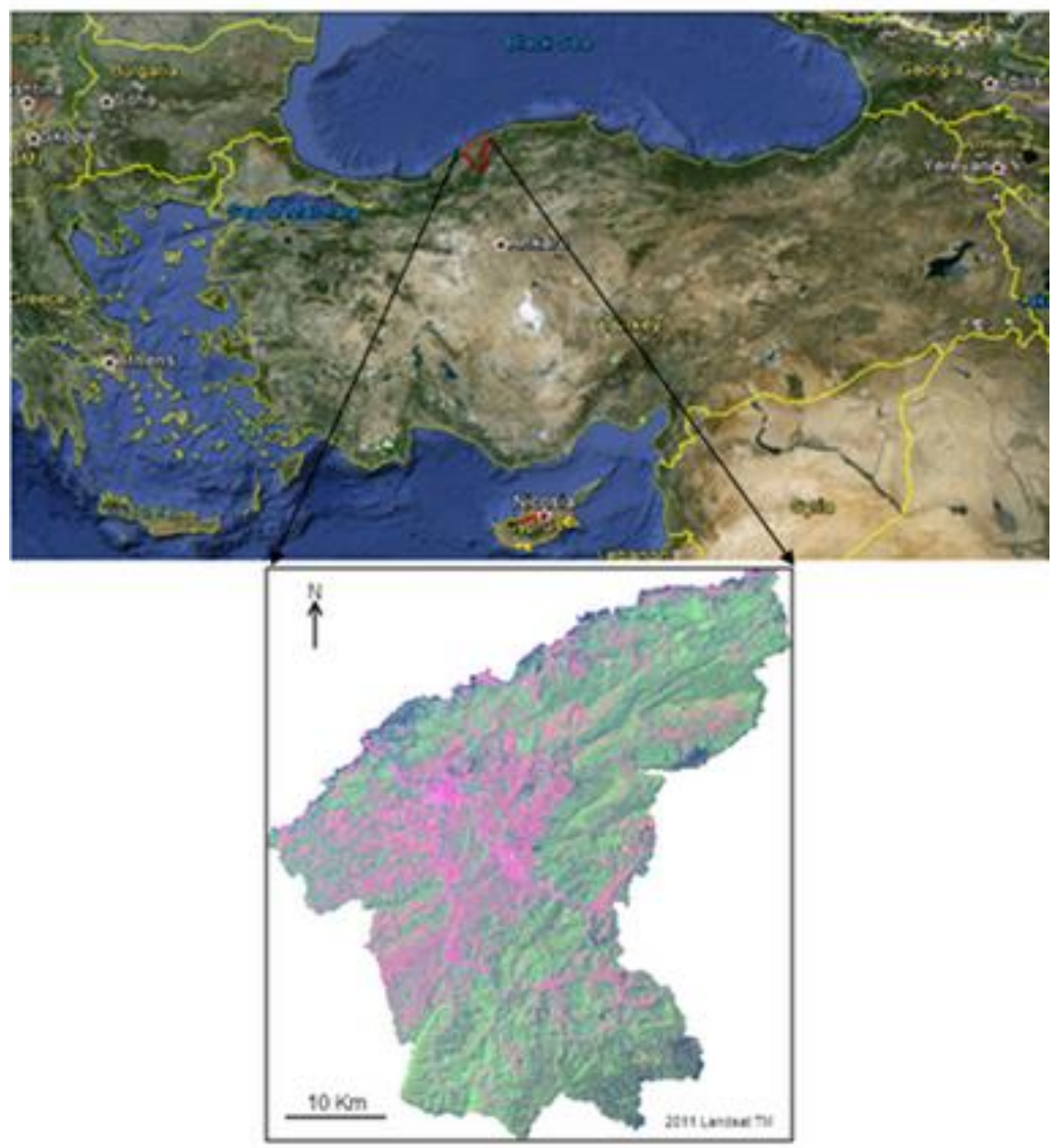

Şekil 1. Çalışma alanı

Çalışma alanı içerisinde 2002-2011 yılları içerisinde toplam 97 yangına ilişkin yangın sicil formu incelenmiştir. Her bir forma ilişkin; meşcere amenajman verileri, meşcere tipi, tarih/mevsim, yangın başlama yeri/noktası, nispi nem, rüzgar yönü, sıcaklık, yükseklik, eğim, bakı bilgileri yer almaktadır. Ayrıca orman yangınları için ülkemiz şartlarında insan kaynaklı etmenleri çok fazla olması nedeniyle yerleşim yeri ve transport ağları Google Earth üzerinden vektörleştirilmiştir. Vejetasyon tipine ilişkin, arazi kullanımın belirlenmesi için 11.06.2011 tarihli Landsat 5 TM uydu görüntü verisi (URL1) kullanılmıştır. Sınıflandırma işlemleri için, topografik haritalar, orman meşcere haritası, CORINE arazi sınıfları haritası, topografik analizler için ASTER DEM 30m kullanılmıştır (Şekil 2). 


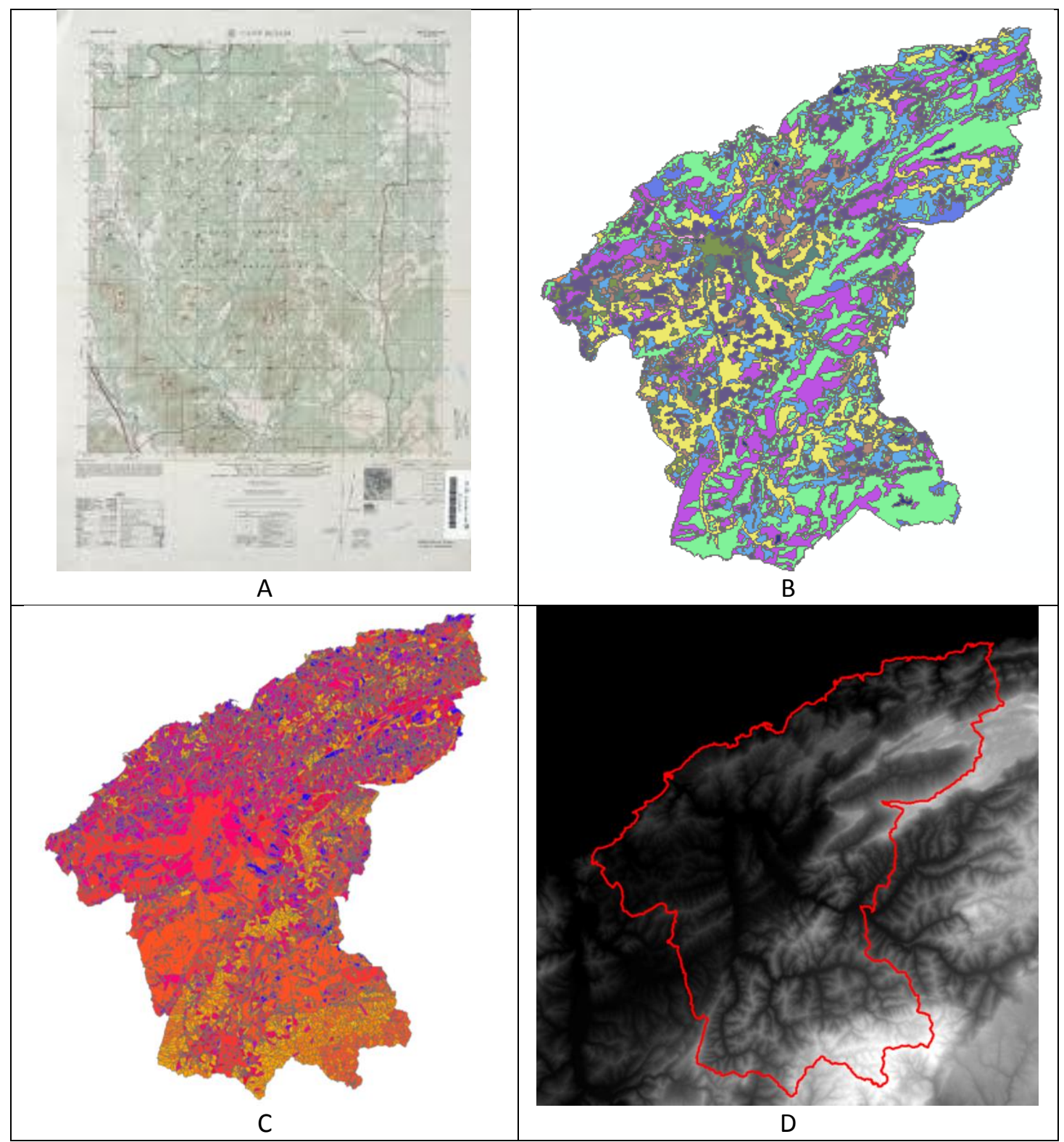

Şekil 2. Topografik harita (A), CORINE arazi sınıfları haritası (B), Amenajman haritası (C)ASTER DEM 30m (D)

\section{Yöntem}

Yangın sicil formlarına ait koordinat ve mevki tanımlarından yola çıkarak, yangın çıkan yerler uydu görüntü verisi üzerinde işaretlenmiştir (Şekil 3). Yangın formlarının inceleme neticesinde, yangın başlama noktaları ve bölme numaraları tespit edilmiştir.
Bölgedeki geleneksel arazi kullanımı, yangın sicil fişleri ve ilgili işletme şefleri görüşleride alınarak çalışma alanı içerisinde orman yangınlarına neden olan en önemli etmenler belirlenmiştir. İlk olarak çalışma alanına ilişkin orman yangınlarında etkili arazi örtü tipi/vejetasyon durumu, eğim, bakı, yükseklik, yerleşim ve yol durumu olmak üzere toplam altı önemli faktör tespit edilmiştir. Kriterlerin belirlenmesinden sonra 
değerlendirmeye alınan her bir kriter için uygunluk puanları saptanmıştır. Bu puanların saptanmasında karar verme süreçlerinin daha sağlıklı bir şekilde işletilmesi amacıyla oluşturulmuş bir yaklaşım olan Analitik Hiyerarşi Süreci (AHP) (Saaty 1980; Yaralığlu, 2004) kullanılmıştır. AHP sonuçlarına göre her bir faktörün ağırlık faktör katsayı belirlenmiştir. Her bir faktöre ilişkin katsayılar ilgili faktörün etki değeri olarak ilişkilendirilerek CBS ortamında yangın tehlike haritası oluşturulmuştur. Yüksek, orta ve düşük olmak üzere üç sınıfta gruplanan yangın tehlike haritasının yüksek ve orta sınıfta yer alan alanların müdahale sınırları tespit edilmiştir. Orman yangınlarında kullanılan arazözler 40 bar su ve kimyasal maddelerin püskürtme yeteneğine sahiptir. Arazözlerdeki su basıncı düşeyde $10 \mathrm{~m}$ başına 1 bar olduğundan, arazi eğimi fark etmeksizin her bir arazöz $400 \mathrm{~m}$ çapı olan bir alanda müdahale edilebilmektedir. Tüm yol ağı çıkartılan çalışma alanının 400 m müdahale maksimum tampon (buffer) alanları CBS ortamında tespit edilmiştir. Potansiyel orman yangını tehlike gruplarına göre bu alanların risk alanlarına dağılımları oluşturularak risk dağılımlarına göre mevcut yol ağlarının yeterliliği tartışımıştır.

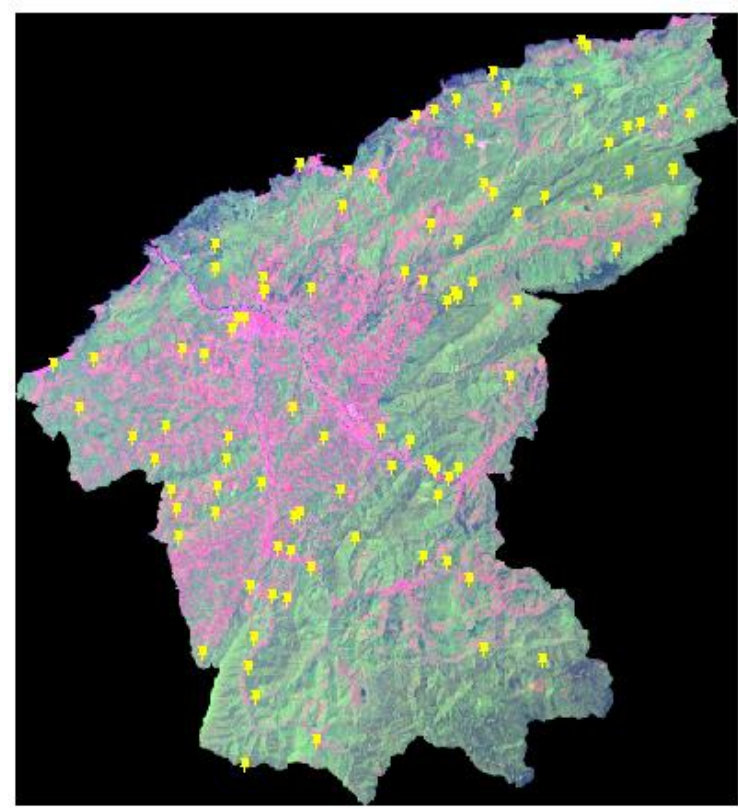

Şekil 3. 2002-2011 yılları içerisindeki orman yangın yerleri

\section{BULGULAR ve TARTIŞMA}

Yangın formlarının değerlendirmesi neticesinde, topografik faktörler dışında elde edilen bilgiler incelendiğinde, yangınların \%44'ü Temmuz ve Ağustos ayı içerisinde gerçekleşmiştir. Ortalama sıcaklığın 24-33 ㅇ aralığında olduğu zamansal periyotda mevcut yangınların \%51'i gerçekleşmiştir. Aynı şekilde yangınların \%44 ile en yoğun görüldüğü bağıl nem aralığı \%30-50, \%56 ile en yoğun görüldüğü rüzgar hızı aralığı 2-4 $\mathrm{m} / \mathrm{sn}, \% 81$ ile en yoğun görüldüğü rüzgar yönü kuzeybatı, batı, güney ve kuzey yönlerindedir.

Sınıflandırma haritası oluşturulurken kontrol alanları Meşcere haritası, topografik harita ve 
CORINE arazi sınıfları haritası verileri vektörleştirilerek gerekli analizler için GIS üzerinden alınmıştır. Sonuç ürün olarak, Landsat 5 TM uydu görüntü verisi üzerinden sosyal baskılı alanlar ve bozuk meşcerelerin belirlendiği bir sınıflandırma haritası üretilmiştir. Koordinat sistemi olarak WGS 84 UTM 36N koordinat sistemi tanımlanmıştır (RMS: \pm 0.6245$)$. Genel doğruluğu \%92 olarak gerçekleştirilen sınıflandırma neticesinde "karışık-geniş yaprakları ormanlar", heterojen tarım alanları/doğal bitki örtüsü ile birlikte bulunan tarım alanları" ve "diğer alanlar" (tarım, yerleşim, açık alanlar, endüstriyel alanlar vd.) olmak üzere 3 sınıf tespit edilmiştir (Şekil 4).

Google Earth kaynaklı çalışma alanı ortamına aktarılmış ve yol ve yerleşime ait koridor alanları belirlenmiştir. Tüm topografik şartların belirlenmesi amacıyla ASTER DEM 30m (Global) verisi kullanılmıştır. Eğim, bakı ve yükseklik haritaları oluşturulmuştur.

Uydu görüntü verisi üzerinden elde edilen sınıflandırma görüntü verisi, ASTER DEM $30 \mathrm{~m}$ (Global) kullanılarak elde edilen eğim, bakı ve yükseklik haritaları piksel boyutu $30 \mathrm{~m} \times 30 \mathrm{~m}$ olarak değerlendirmeye alınmışlardır. Yerleşim ve ulaşıma ait vector katmanlar da yine aynı piksel boyutunda raster verisine dönüştürülmüş ve analize hazır hale içerisindeki tüm yol ve yerleşime ait alanlar getirilmiştir (Şekil 5)

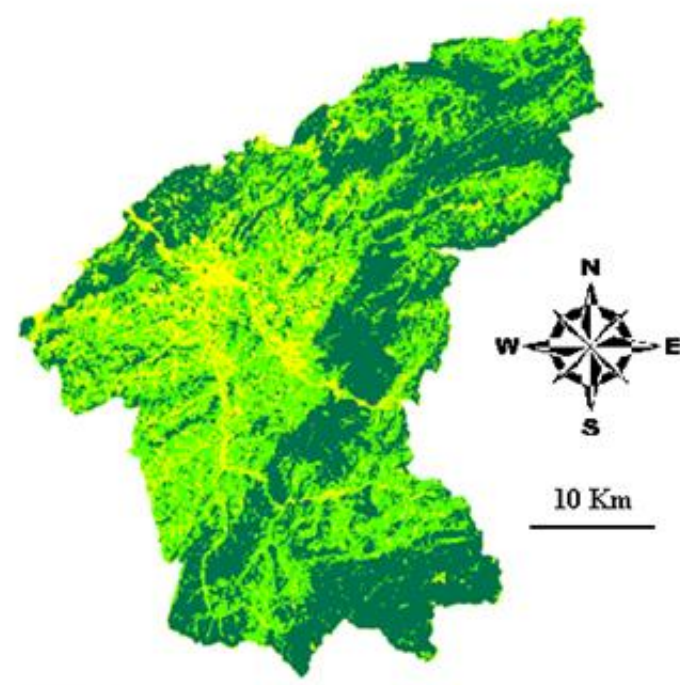

Karnsk ve genis vapraklh ormanlar

Heterojen yapıda doğal bitki örtüsü ile birlikte bulunan tarm alanlan

Diğer alanlar (yerleşim, yol, kayallk vd.)

Şekil 4. Sınıflandırılmış Landsat 5 TM uydu görüntü verisi 

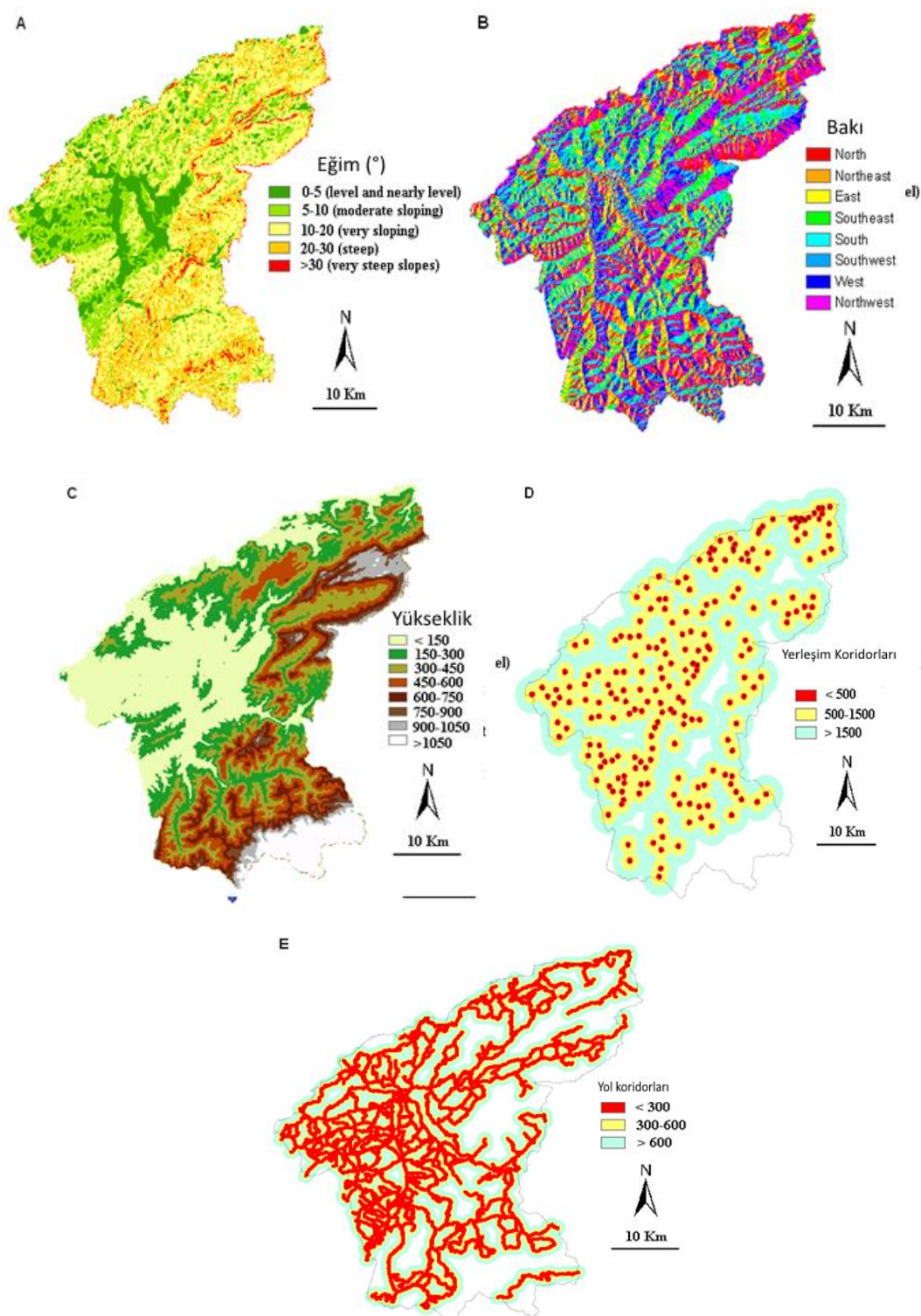

Şekil 5. Eğim (A), Bakı (B), Yükseklik (C), Yerleşim Koridorları (D) ve Yol koridorları (E) haritaları

Tespit edilen faktörlerin önem dereceleri karar vericiler tarafından belirlenmiş ve bu kapsamda önceden tanımlanmış olan (1-9) puanlama yapılmıştır. Çalışmada değerlendirmeye alınan kriterlerin ağırlık puanları AHP tekniği ile belirlenirken; ilk adımda her bir kriterin etki durumu göz önünde bulundurularak ikili karşılaştırmaların yapıldığı matrisler oluşturulmuş; ikinci adımda her bir tablodaki matrisin en büyük kriterlerin ağırlık değerleri hesaplanmış, yöntemin son adımında ise elde edilen özvektörün tutarlılık kontrolü yapılmıştır (Çizelge 1). 
Çizelge 1. Orman yangınına etki eden kriterlerin ikili karşılaştırmaları ve ağırlık değerleri

\begin{tabular}{llllllll}
\hline Değişkenler & C1 & C2 & C3 & C4 & C5 & C6 & Ağırlık puanı \\
Arazi örtü tipi/vejetasyon durumu(C1) & 1 & 3 & 5 & 4 & 5 & 3 & 0.41 \\
Eğim (C2) & $1 / 3$ & 1 & 3 & 2 & 3 & 1 & 0.18 \\
Bakı(C3) & $1 / 5$ & $1 / 3$ & 1 & $1 / 2$ & 1 & $1 / 3$ & 0.06 \\
Yükseklik (C4) & $1 / 4$ & $1 / 2$ & 2 & 1 & 2 & $1 / 2$ & 0.11 \\
Yerleşim durumu(C5) & $1 / 5$ & $1 / 3$ & 1 & $1 / 2$ & 1 & $1 / 3$ & 0.06 \\
Yol durumu(C6) & $1 / 3$ & 1 & 3 & 2 & 3 & 1 & 0.18 \\
1: Öğeler eşit derecede öneme sahiptir. & & & & & & & \\
3: 1. ölçüt 2.'ye göre biraz daha önemlidir. & & & & & & \\
5: 1. ölçüt 2.'ye göre fazla önemlidir. & & & & & & \\
7: 1. ölçüt 2.'ye göre çok fazla önemlidir. & & & & & & \\
9: 1. ölçüt 2.'ye göre olası en kuvvetli öneme sahiptir. & & & & & \\
2,4,6,8: İki yakın ölçek arasındaki uzlaşma gereken ara değerdir. & & &
\end{tabular}

Consistency Ratio: 0.011

Formül 1'e göre her bir piksel için yangın tehlike puanları CBS "Spatial Analyst" modulu yardımıyla hesaplanmıştır.

$S=\sum_{i=1}^{n}\left(w_{i} x_{i}\right)$

( $S$; toplam yangın tehlike puanı; $w_{i}$; kriterlerin ağırlık değeri, $x_{i}$; kriter puanları, $n$; toplam kriter sayısı)

Bartın OiM'de gerçekleşen yangın alanlarına ait tüm özellikler ve yetkili uzman kişilerin görüşleri doğrultusunda, belirlenen faktörlerden ağırlık değeri en fazla olan $41 \%$ değeri ile bitki örtüsü olmuş, daha sonra $18 \%$ ağırlık değeri ile eğim (C2) ve yol durumu (C6) gelmektedir. Orman yangınlarını oluşturan ana faktörler topografya, arazi kullanımı ve vejetasyon örtüsüdür. Analizin son aşamasında CBS ortamında belirtilen yangın tehlike sınıflarına uygun oluşturulan yangın tehlike sınıfları haritası Şekil 6'da verilmiştir.

Elde edilen verilerin CBS ortamında değerlendirilmesi sonucu ulaşılan yangın tehlike haritası incelendiğinde, toplam alanın \%15'i $(26.083,4$ ha) yangına karşı en hassas olan yüksek risk sınıfında yer aldığı görülmüştür. Yine, toplam alanın yaklaşık \% $31^{\prime} i \mathrm{(53.905,7}$ ha) orta derecede hassas olan yerlerde kaldığı belirlenmiştir. Geri kalan \% 54 'lük (93.900,3 ha) alanın ise yangın riski bakımından düşük olan grupta yer aldığı belirlenmiştir.

Araştırma kapsamında elde edilen bulgular sonucu, Bartın OiM alanının yaklaşık yarısını kapsayan (\%46) yangın riski orta ve yüksek bulunan alanlara yollar ile ulaşım değerlendirilmiştir. Bu amaçla, elde edilen yangın risk haritası üzerinde karayolu, orman yolu, yangın emniyet yol ve şeritleri yerleştirilmiştir. Mevcut yol ve şeritlerin tarafında arazözlerin ulaşım alanı kabul edilen her iki yönde 400 metrelik tampon bölgeler belirlemiştir. Bu mevcut yol ağı ve ulaşım alanı yangın riski tehlike haritası üzerine aktarılarak yangın risk oranı yüksek ve orta olan bölgeler için arazözle müdahale alanları haritası oluşturulmuştur (Şekil 7). 


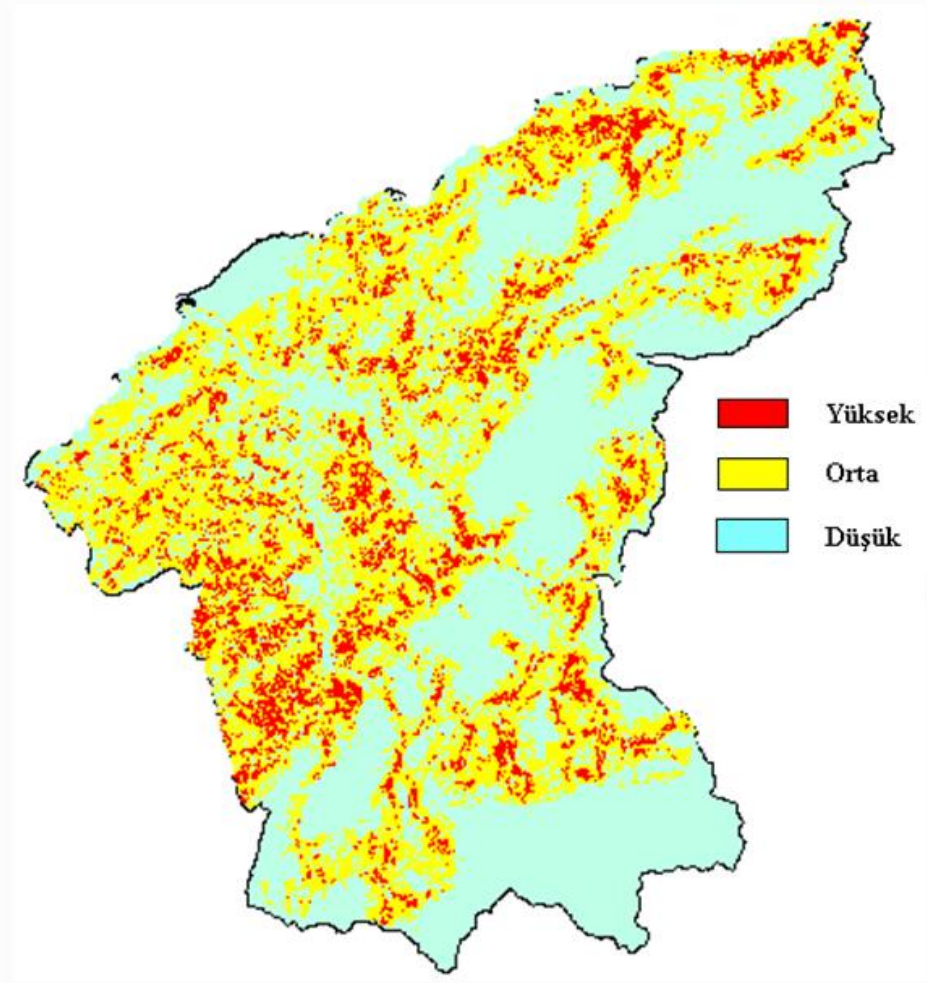

Şekil 6. Bartın Orman İşletme Müdürlüğü yangın tehlike haritası (Yangın Tehlike İndeksi $=0.41 \mathrm{C} 1+0.18 \mathrm{C} 2+$ $0.06 C 3+0.11 C 4+0.06 C 5+0.18 C 6)$

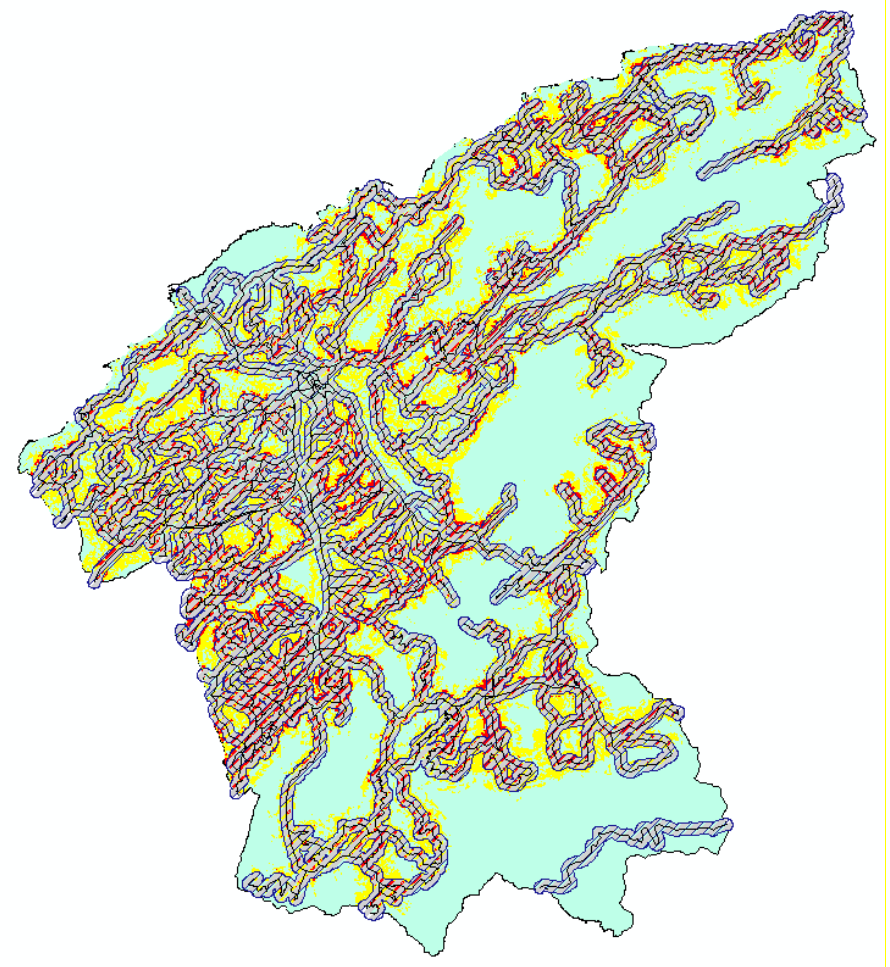

Şekil 7. Yangın risk bölgeleri için arazözle müdahale alanları haritası 
Yangın riski açısından orta ve yüksek risk grubunda yer alan toplam 80821.61 ha alan üzerinde, mevcut tüm yollar kullanılarak arazözle yangına müdahale alanları toplamı 54427.62 ha olarak bulunmuştur. Bu durum yangın riski orta ve yüksek alanların \% 67.3'lük kısmına müdahale edilebilir olduğu belirlenmiştir. Yangına hassas bölgelerde orman yolları en kısa yoldan yangın noktasına ulaşılarak, yangının etkisini düşürmeyi sağlar. Dolayısıyla, orman yolu, yangın emniyet yol ve şeritlerinin planlamasında sadece orman ürünlerinin transportu değil, orman alanlarının yangına hassasiyet durumları da gönünde bulundurularak yapılmalıdır.

\section{SONUÇ VE ÖNERILER}

Bartın OiM için CBS ve UA teknikleri kullanılarak üretilen yangın risk sonuç haritasına göre, toplam alanın \%15'i yangına karşı en hassas olan yüksek risk sınıfında, yaklaşık \% 31'i orta derecede hassas olan sınıfta, \% 54'ü de düşük olan grupta yer almaktadır. Toplam 80821.61 ha. alan yangın riski açısından yüksek ve orta kısımda yer alırken, mevcut yollar kullanılarak arazözle yangına müdahale alanları toplamı 54427.62 ha olduğu belirlenmiştir. Bu durum yangın riski orta ve yüksek olan alanların \% 67.3 kısmı müdahale edilebilir olduğunu göstermektedir.

CBS tabanlı yazılımların çok kriterli analizler yardımıyla yangın tehlike haritalarının oluşturulması ve belirli periyotlarda tekrarlanması faydalı olacaktır. Benzer olarak arazi sınıflarının uzaktan algılama verileri ile üretilmesi ve oluşturulan modele dahil edilmeleri, haritalar gibi güncel olmayan verilerin kullanılmasının doğru bir alternatifi olacak ve yapılan çalışmaların başarısını artıracaktır. Özellikle yangına hassas bölgelerdeki orman yollarının planlamasında, orman ürünlerinin transportu yanında, orman alanlarının yangına hassasiyet durumları da gönünde bulundurularak yapılmalıdır. Yangın emniyet yol ve şeritleri, yangına orta ve yüksek hassas olan bölgelerdeki müdahale edilebilir alan oranları belirlenerek planlanmalıdır. Orman yangınlarına müdahaleye yönelik uygulanan ve bir altık oluşturan bu araştırma yönteminin yangına hassas diğer bölgeler için de geliştirilerek yaygınlaştırılması ülkemiz ormancılığı açısından faydalı olacaktır.

\section{TEŞEKKÜR}

Bu çalışma, Bartın Üniversitesi Bilimsel Araştırma Projeleri Birimi BAP-2013.2.97 nolu proje kapsamında desteklenmiştir.

\section{KAYNAKLAR}

Atesoglu A, Tunay M (2010) Spatial and temporal analysis of forest cover changes in the bartin region northwestern turkey, African Journal of Biotechnology, 9(35): 56-76

Ateşoğlu A, (2014) Forest fire hazard Identifying. mapping using satellite imagery-geographic information system and analytic hierarchy process: Bartin, Turkey, Journal of Environmental Protection and Ecology, 15(2): 715-725

Bilgili E, Baysal, I, Durmaz B, Dinç B, Sağlam, B, Küçük, Ö (2008) Spatio-temporal analysis of forest fire risk and danger using Landsat imagery, Sensors, 8: 3970

Brown A, Davis K P (1973) Forest Fire: Control and Use. Mcgraw-Hill Book Company, New York

Bilici E (2009) Orman yangın ve emniyet yolları ve şeritleri ile orman yol şebekelerinin entegrasyonu, planlanmaları ve uygulamaları üzerine bir araştırma (Gelibolu Milli Parkı Örneği), İstanbul Üniversitesi Orman Fakültesi Dergisi, Seri: A, 59 (2): 85-101

Burke C J (1980) Historic fires in the central western cascades, Oregon, Phd Thesis, Oregon State University, USA 
Caldararo N (2002) Human ecological Intervention and the role of forest fires in human ecology, The Science of the Total Environment, 292, 141

Castro R, Chuvieco E (1998) Modelling forest fire danger from geographic information systems, Geocarto International, 13(1): 15-24

Çanakçıŏlu H (1993) Orman Koruma, İstanbul Üniversitesi Orman Fakültesi, Yayın No. 411, 633 s, İstanbul

Çepel N (1983) Orman Ekolojisi. İstanbul Üniversitesi Orman Fakültesi, Yayın No. 211, İstanbul

Dong X, Shao G, Limin D, Zhanqing H, Lei T, Hui W (2006) Mapping forest fire risk zones with spatial data and principal component analysis, Science in China: Series E Technological Sciences, 49: 140-146

Gillett N P, Weaver J, Zwiers F W, Flannıgan M D (2004) Detecting the effect of climate change on canadian forest fires, Geophysical Research Letters, 31, L18211

Goldammer J G, Nikolov N (2009) Climate change and forest fires risk, european and mediterranean. In: Workshop Climate Change Impact on WaterRelated and Marine Risks, Murcia, October

Inan M (2004) Orman Varlığının Saptanmasında Uzaktan Algılama Verileri, İstanbul Üniversitesi Fen Bilimleri Enstitüsü, Orman Mühendisliği Anabilim Dalı, Ölçme Bilgisi Ve Kadastro Programı Doktora Tezi, İstanbul, syf. 187

Jian Y, Healy H S, Shifley S R, Gustafson E J (2007) Spatial patterns of modern period human-caused fire occurrence in the missouri ozark highlands, Forest Science, 53(1): 1-15

Jo M, Le M, Lee S, Jo Y, Baek S (2013) The development of forest fire forecasting system using internet GIS and satellite remote sensing

Kılıç H (2012) Orman Yangınları Ve İnsan Illişkisi: Antalya Orman Bölge Müdürlüğü Örneği. Çankırı Karatekin Üniversitesi, Fen Bilimleri Enstitüsü, Y. Lisans Tezi, 122

Melemez K (2013) An environmental assessment of forest stands damages caused by excavators during road construction in Beech forests, International Journal of Environmental Science and Technology, 10(4):645-650
Mol T ve Öymen T (1988) Yangında ulaşımın önemi. Tarım Orman ve Köyişleri Bakanlığı, Orman Genel Müdürlüğü, Türkiye Ormanlarını Yangından Koruma Semineri, 4-8 Mayıs 1987, Yayın No. 29, Seri No. $672,288-291$

OGM (2010) Orman Yangınlarıyla Mücadele Eylem Planı. Orman ve Su İşleri Bakanlığı, Orman Genel Müdürlüğü, Ankara, 2010

OGM (2013) Türkiye'deki orman yangınları. Orman ve Su İşleri Bakanlığı, Orman Genel Müdürlüğü. http://www.ogm.gov.tr/

Özturk M, Gücel, M, Küçük S, Sakçalı (2010) Forest diversity, climate change and forest fires in the mediterranean region of Turkey, Journal of Environmental Biology, 31, 1

Pinol J, Teradas F, Lioret (1998) Climate warming wildfire hazard and wildfire occurrence in Coastal Eastern Spain, Climatic Change, 38, 345-357

Razali S M, Nuruddin A A, Malek A I, Patah A N (2010) Forest fire hazard rating assessment in peat swamp forest using Landsat thematic mapper image, J Appl Remote Sens, 4(1): 543-53

Saaty T L (1990). How to make a decision: The analytic hierarchy process, European Journal of Operational Research, 48: 9-26

Sağlam B, Bilgili E, Durmaz B, Kadıoğulları A I, Küçük O (2008) Spatio-temporal analysis of forest fire risk and danger using Landsat imagery, Sensors, 8, 3970-3978

Setiawan I, Mahmud A R, Mansor S, Mohammed Shariff A R, Nuruddin A A (2004) GIS-Grid-Based and multicriteria analysis for identifying and mapping peat swamp forest fire hazard in Pahang, Malaysia, Disaster Prevention and Management, 13(5) 379386

Yaralıoğlu K (2004) Uygulamada Karar Destek Yöntemleri, ilkem Ofset, İzmir

Zhihua L, Yang J, Chang Y, Weisberg, P J, He H S (2012) Spatial patterns and drivers of fire occurrence and its future trend under climate change in a boreal forest of northeast china, Global Change Biology, 18(6): 2041-2056 